\title{
Reading Kaushalya Baisantry's Dohra Abhishaap: A Modern Idiom of Dalit Female Subjectivity
}

\section{Sonali Maurya}

Research Scholar, Centre for Linguistics, Jawaharlal Nehru University, New Delhi, India

\begin{abstract}
The emergence of Dalit autobiography offers a new dimension to the study of the literary genre of autobiography. This paper explores the intersectionality of caste and gender and liberation issues through the critical reading of Kaushalya Baisantry's Dohra Abhishaap, a Dalit autobiography written in Hindi. And, how the act of writing life narratives by Dalit women smashes the misconstruction/misreading of their agency by deconstructing their traditionally assigned identity and reconstructing their autonomous agency. It also sets up the manifestos for Dalit women's liberation through the textual construction of Dalit female 'self.'
\end{abstract}

Keywords-Dalit autobiography, Caste, Gender, Patriarchy, Dalit identity, Dalit feminism, Mainstream feminism.

Kaushalya Baisantry's Dohra Abhishaap (Twice Cursed) was published in 1999, which unfolds the tremendous struggle of Dalit women; and the rise of Dalit Chetna in general, and Dalit women's Chetna in particular; also, it exhibits Dalit men-women relationship within the family set up. Unlike other autobiographies, her autobiography not only expresses feelings of extreme pain, hatred, and nausea but also deals with her parents' struggle along with her own. This narrative is an honest exposition of the merits and demerits of the Dalit community by the author's lens. Baisantry is an Ambedkarite activist and a founding member of 'Bhartiya Mahila Jagrati Parishad.' And, her narrative voice of 'we' instead of 'I' is suggestive of collective consciousness or 'communal self' since through the technique of individual 'female self,' she narrates the multiple female selves. Her narrative focuses on locality, surrounding, the struggle for education, and the looming presence of caste. She kept living her life with memories of the past. And, 68 years of her life have been passed only in the conflict of turning her yatharth (livedexperience) into meaningful words. This narrative relates the stories of three generations of Dalit women's struggle, assertion as well as the construction of self in particular. Also, it underlines the corporeal ache and psychological anxiety meted out to Dalit women within and outside the family structure. Baisantry's autobiography explores Dalit women's pathetic situation in society. Their status of 'Dalit in Dalits' as they are doubly and triply cursed and exploited based on caste, class, and gender. For instance, they are subjected to exploitation at public workplaces and the victim of the caste system as well as patriarchy within and outside of the Dalit community. According to Vimal Thorat, "Dalit feminist writing like that of Kaushalya Baisantry's Dohra Abhishaap (Twice Cursed) speaks of the combined curses of untouchability and patriarchy."1 In Dalit women's autobiographies, the expressed context, location, problem, and conflict are the main highlight. The struggle of a Dalit woman to get an education and cope with odds that come at every step of growth is a significant highlight of the narrative. Moreover, Dalit identity, gender normativity, and its naturalization by society are some significant issues dealt by the narrator; further, Dalit women's hard efforts to become financially self-reliant and their struggle with starvation remained the areas of anxiety for them. Being a woman, one has to go through multiple layers of exploitation, disregard, and disrespect within and outside domestic spheres. Autobiographer has prominently depicted these contexts, incidents, and conflicts in her autobiography.

\footnotetext{
${ }^{1}$ Thorat, Vimal. Dalit Women's Voices Must Define Indian Feminism, 21 May 2016.
} 
Baisantry was neither a writer nor a litterateur, but being born in a Dalit community, she has undergone physical and mental humiliation owing to the discriminatory caste system and intrinsic patriarchy in Indian society that established her reputation as a writer. In a male-dominated society, women always have a subservient role to play, and society remains fervent to confer character certificates to women. She writes, "My son, brother, and husband could all be angry with me, but I also want the freedom to put my thoughts in front of society. There are large numbers of women like me, who are afraid of exposing their experiences in public due to fear of society and family; they live in suffocation throughout their life. Such experiences are needed to come out as the eye-opener of society."2 Baisantry has been a student activist and was associated with 'Asparshya Vidhyarathi Parishad' constituted for Dalit academic problems and their guidance. The author was the joint secretary of this organization and also the executive council of Asparshya Vidhyarathi Parishad. She had to bear numerous derogatory comments due to her activism and interaction with boys.

To talk about Dalit female 'self' and their quest for the agency in Dalit women discourse is pertinent as well as challenging. It is because this section of society neither gets expression in mainstream feminism nor Dalit discourse. Though we have more excellent opportunities for women in the present time yet, the majority of Dalit women are still far away from education and occupation. In such a situation, this narrative powerfully raises the question of being and becoming of Dalit women, who remained deprived of their fundamental rights and social existence until now, focusing on the socio-cultural conditioning of Dalit women's autobiographies. The attempt is to highlight the dual exploitation of women employing socio-cultural tools as the subject matter of Dalit women's autobiographies. The narrator throws light on the existing differential and traditional discriminatory practices in the Dalit community as there are different traditions for marriage and remarriage of a Dalit widow and Dalit widower. Baisantry unravels many prejudices and social evils within the Dalit community, i.e., girl-child marriage and polygamy, that a Dalit man can have more than one wife at a time which was considered the matter of pride and privilege for that man. Baisantry's aaji (grandmother) gets married when she was just eight years old

\footnotetext{
${ }^{2}$ Baisantry, Kaushalya. (1999). Dohra Abhishaap. From Preface of the autobiography. Delhi: Parmeshwari Prakashan.
}

and subjected to widowhood at a very young age. Unlike privileged castes, widow and divorcee remarriage haven't been problematic of the Dalit community; instead, it has different methodologies to remarried, which is called paat ${ }^{3}$ that is different from the marriage ceremony. Due to child marriage, Dalit women are destined to widowhood at a very young age that raises another issue of the widow and their children's upbringing and survival due to harsh and restrict socio-cultural rules for them. The author's aaji and her father's mother had to live a torturous life of widowhood. Thus, the autobiographer criticizes its discriminatory nature, as a Dalit widower can remarry to an unmarried girl but a Dalit widow or divorced woman cannot get paat again with an unmarried man, and usual remarriage wasn't allowed for them.

Now the scenario has been changed, and these types of customs are not present in the Dalit community, but girl child marriage and widowhood are still problematic. Subsequently, her aaji got paat at the age of 13 with a man who already had a wife. Having a ferocious and shrewish attitude, Ajoba (aaji's second husband) reproached and violently beaten up aaji every day, and she had to bear everything. The author writes, "She gets fed up with such a life. But what would she do? Where does she go? And, one day, her patience was overdone." ${ }^{4}$ Finally, she leaves her brutal husband's house with her three children and decided to live the rest of her life on her own with self-respect, and she never went back to Ajoba, author's aaji showed this kind of resistance. Until the last breath, she lived and left with selfesteem. She dies carrying all the articles for her last funeral rituals that show the degree of svabhiman (self-respect) she had. Both women characters (the author's aaji and mother) emerged as powerful women who have an independent identity from their husbands and have their own decision making power. Her aaji is an exemplar of self-respect and self-independent persona. "These self-consciously assumed identities of self-assertion and reaffirmation in the life narratives contradict the presumed passivity of Dalit women and do away with the imposed identities of the "pitied" and the "mute" subject."5

\footnotetext{
${ }^{3}$ Paat is a prevalent custom for a widow and widower's remarriage in the Dalit community, which is not existent now a day.

${ }^{4}$ Baisantry, Kaushalya. p. 19.

${ }^{5}$ Naik, Purnachandra. "Baby Kambale to Bama: Dalit Women Write Differently", Economic and Political Weekly. Vol. No. 42, October 15, 2016.
} 
Baisantry's husband, Devendra Kumar Baisantry, was a prominent writer and a freedom fighter, but he fails to avail gender equality and liberty to his wife. For him, his wife is no more than an object or just an enjoyable 'instrument' for his pleasure, not even a sexual subject whose desires and happiness are also taken into account. As the author writes, "Devendra Kumar (my husband) needed a wife only to prepare meals and to satisfy his physical hunger."6 "Kaushalya Baisatry's Dohra Abhishaap recounts the author's narrative of domestic abuse and her final separation from her husband, a civil servant, after 33 years of her marriage. Vimal Thorat stated that this account was an eye-opener for the Dalit middle class."7 Baisantry has depicted double standards not only of upper-caste men's but also of Dalit men's. She writes in the preface that, "my highly educated husband, a writer who presided at the highest position in the Government of India, who received 'tamrapatra' and pension of a freedom fighter, never valued me. Albeit, I was forced to leave the house and then only filed a court case against him." 8 Despite being educated, the author continued to suffer throughout her life; and her husband remained insensitive and intolerant despite being a highly qualified man. He used to say that "he is a devil," who never cared for his wife's happiness and used to beat her mercilessly along with filthy abuses. Moreover, the author is well educated, but she doesn't have any job and financially dependent on her husband, who keeps his belongings and money in a locker. For some time, he used to give his wife 40 rupees per month as a pagaar (salary) as if she was his maid, not a partner. Later on, he stopped giving that money too. According to Udaya Kumar, "the experience of humiliation produces its own structures of subjectivity." He further adds, "the humiliated subject is understood as lacking in agentiveness; agency is to be found in the response to humiliation, in the choice the subject makes in the face of the humiliating act."9 And, the author being conscious of her exploitation, stopped washing his clothes and cooking food for him and raised her voice against domestic violence and

\footnotetext{
${ }^{6}$ From Preface of the autobiography Dohra Abhishaap.

${ }^{7}$ Thorat, Vimal. Caste and Gender in Dalit Feminist Writing.

${ }^{8}$ From Preface of the autobiography Dohra Abhishaap.

${ }^{9}$ Kumar, Udaya. "Consciousness, Agency and Humiliation:

Reflections on Dalit Life-writing and Subalternity." The

Politcal Philosophies of Antonio Gramsci and B $R$

Ambedkar: Itineraries of Dalits and Subalterns, edited by

Cosimo Zene, 2013, p. 166.
}

gender equality. Ultimately, she decided to stay away from her husband, filing a case against him to resist humiliation.

After marriage, the narrator enters a new Hindi speaking family with a patriarchal structure where women don't usually speak before men, especially husband and brother. The inter-caste and inter-state court-marriage of the author shows a progressive outlook of her by rejecting the Hindu view of marriage, at a time when this kind of marriage was neither unproblematic nor an easy task. But, Devendra's behavior towards his wife was that of a male patriarch who failed to see her beyond a body. However, the narrator came from a family where her mother has equal rights and decisive power. Unfortunately, she gets a family that is utterly feudal in structure. In the Hindi belt, there are specific rules or stereotypes, and both the genders have different sets of works as women are assigned with domestic chores and men with public work, and violation of these rules is considered objectionable. Even a woman with great achievements and good social relations has to leave all this just after her marriage because of her husband's will. And, the husband becomes a master of his brilliant wife. All this is the experiential reality of the narrator just after her marriage.

The writer faces terrible poverty since her childhood, and due to illiteracy and superstition, her parents give birth to many children. She has eleven siblings; however, only five sisters and a brother are alive; the rest couldn't survive owing to extreme poverty and starvation. Dalit narrator's critical observation on misuse/exploitation of human labor and appropriation of its benefit by particular castes and class is well depicted in this writing is equivalent to a competent economist. The author belongs to the Mahar community, and his father used to work in the Britishers' Club, and his family depended on Britishers' 'joothan' (leftover) and some money as bakhshish (tips/gifts). Later on, he began to work in a Parsi bakery, but during this job, his salary never increased where he was working for the last 20 years, and ultimately he had to quit this job. The author's self-respecting mother didn't like to see her husband doing begaar $^{10}$ and firmly decided to quit that work. Her resistance and consciousness against begaar and economic exploitation can be seen in this extract, she writes, "my mother grabbed Baba's hand in front of the bakery woman and pulled him out of the bakery and tells the bakery woman. You make my husband do so much work and don't even value it. You did

${ }^{10}$ This is forced labour without pay or minimum pay or less pay than the labour. 
not even raise a penny for many years. Now I will not let him work here. Even if we remain hungry, we will not let him work here." ${ }^{11}$ The author's family was often made to realize their Dalitness. Time and again, her mother faced untouchability during bangle selling when savarna women used to take a bath after getting bangles from the author's mother because she was untouchable. Though, she bears this humiliation and disrespect for livelihood. Repeatedly, going through the same experience, she couldn't hold her patience and stopped selling in that so-called upper caste locality, and scolds them in these words, "why you don't care about my caste when you have your self-vested interest?"12 Purnachandra Naik argues about Dalit women that, "they are far from being "silent subjects" at the receiving end of humiliation."13

The author argues it is not only the Hindu/Brahmin women, who practice untouchability but the Muslim and Gond Adivasi do the same to the Mahar community. And, Gond Adivasis themselves face discrimination from Hindus, but they maintain distance with Dalits. Adivasis, too, live in wretched conditions akin to Dalits and are backward in education and lifestyle. Also, not allowed to touch or sit in Hindu upper-caste houses, though they are not impure. One of the authors, Adivasi friends Jangla, scolds her for touching water pitcher as the author writes, "Jangla screamed why did you touch the pitcher? Now, we have to throw the pitcher." 14 However, the author was too young to understand how the mere touch could pollute the pitcher. Baisantry further adds that Dalits, too, practice untouchability and look at the lowest rung of Dalits with hatred. For instance, the Mahar community practices untouchability with the Mang, and among the sub-castes of the Mahar community, marriage is not allowed, while interdining is there. Sakhameshram, one of Baisantry's best childhood friends, they loved each other, but he didn't marry her owing to different sub-castes. It was somewhat baffling for the author to know people having the masquerade of progressivism are hypocrites, and he secretly gets engaged with another woman with the same caste.

She further reflects on Dalit and Adivasi women's contribution to her time for Dalit and Adivasi women's

${ }^{11}$ Baisantry, Kaushalya, p. 44.

12 Ibid., p. 85.

${ }^{13}$ Naik, Purnachandra. "Baby Kambale to Bama: Dalit

Women Write Differently”, Economic and Political Weekly.

Vol. No. 42, October 15, 2016.

${ }^{14}$ Baisantry, Kaushalya, p. 88. education and consciousness. Jai Bai Chaudhary, an untouchable woman, runs a school in her house for Dalit women's free education where the author and her sisters received their early education; and an Adivasi woman from Gond community opened a school for Adivasi women too. Both these women used to awaken the Dalit community practicing Mahatma Phule- Savitribai Phule's philosophy of education for 'all' women of society in real terms. The author's mother had too much influence of B R Ambedkar's message to "educate, organize and agitate" To Ambedkar, education was above all; that's what he used to preach to the Dalit community. The celebration of Ambedkar Jayanti is a symbol of Dalit's culture and consciousness. That's why she concentrated on her children's education even in utter poverty; she also gave up worrying about her girls' marriages and became firm to provide them higher education.

Author after leaving Jai Bai's school, she joined Bhide Kanyashala, where she was the only one untouchable student and two girls from Kunbi castes and had to face caste-based discrimination several times. The author being an untouchable, used to feel sad and inferior and always remains scared about her Dalit identity, also she feels insulted because of her father's 'Kabadi' business. Once she was asked by those Kunbi girls about her caste identity, and she replied, "I said out of fear that I am also from Kunbi caste." ${ }^{15}$ The narrator, coming from a lower stratum of Indian society, had to bear the mental trauma of theft allegation at school that was heartbreaking for her. Her parents were unable to pay the school fee and went to request to school teachers that was a very insulting incident for the author. Despite all this, Baisantry was the first metric qualified girl in her basti (locality). However, she had to face humiliating taunts and disgust from upper-castes boys and women during her school days because they don't want Dalits to attain education. Also, they were surprised that how the children of a poor laborer managed to study. The stigma of caste and humiliation of untouchability was so deep that it instilled inferiority within the writer and made her suffer from selfdisgust and self-doubt. Subsequently, the narrator's internalized sense of inferiority stopped her from participating in any school program and sports activities or any extracurricular activities. Baisantry wanted to be an actress and a singer having a melodious voice but couldn't succeed due to the lack of accessibility to resources.

${ }^{15}$ Ibid., p. 41. 
Babasaheb Ambedkar always delivered an inspiring speech for both literate and illiterate women in each talk and meeting. Getting influenced by B R Ambedkar's philosophy, the author used to participate in jan-jagrati (mass awakening) programs participating in street plays and many other cultural forms like Povade, Jalse, Natak and folksongs, etc. The writer happened to meet with $\mathrm{B} R$ Ambedkar during a meeting of "Akhil Bhartiya Asparshya Samaj" (All India Depressed Classes Women Conference) in July 1942, when women did not usually participate in social work. Yet, around 30,000 women turned up, and Babasaheb was pleased to see the women's presence in huge numbers, though most of the present women were uneducated. During this conference at Nagpur, Ambedkar narrates a mythological story of kach and Devyani who earned education with great difficulty. Ambedkar wants Dalit to acquire knowledge at any cost because education is the only way out of all kinds of shackles. And here, the author got the opportunity to interact with those women who had an interest in social work and tried to affiliate them with the organization to strengthen their struggle and organization.

She also reflects on some Dalit male hypocrite politicians and so-called social workers and their objectionable social behavior towards women social activists in the organization. They misbehaved with the author and made her prey of the male gaze instead. The narrator portrays the superficial mentality of Dalit socio-political activists during her activism. And, how she was molested and humiliated at the political sphere as such incidents might demoralize a woman and her family immensely who are socio-politically active. Though, it is adorable that the narrator and her family never lost their patience. There was an incident in the narrative when the gatekeeper of Meyo hospital wanted to sell the author into prostitution for the sake of money.

The author highlighted Dalit men's offensive behavioral patterns towards women's relating narratives of Jayram and Ramkunvar. Jayram used to live on his wife's earning, who works in a mill, and Jayram had a bad habit of gambling; he never cared for his wife. He always makes a lame excuse for his illness. On the day she gets the payment, he used to stand near the mill gate and snatched half of the money from his wife's salary and used to waste that money in gambling and alcohol. Ramkunwar had to bear all this silently. Though, she had an extramarital affair with a co-mill worker. And, wife of her lover used to abuse Ramkunvar because, according to her, a man could have an extramarital relationship out of male privilege, but how come a woman does that? In short, she was unable to stop her husband, that's why she argues, "he is a man, but a woman should always maintain her dignity." ${ }^{16}$ It implies that all sins of a man are justified but not a single mistake of a woman. The author is surprised, looking at such an attitude of a woman for another woman that shows fractions and disunity even among Dalit women itself.

The second narrative is of Sakharam, and his beautiful wife, who used to work as a daily wage worker, and his wife became the prey to sexual harassment at the workplace. When she complaints about Mason's unacceptable behavior to her husband, Sakharam, who instead of saying anything to Mason, blamed his wife. As he argues, "why does he molest you only? You are the raff."17 In order to punish her, a garland of slippers was put around her neck and was paraded, placing her on a donkey, in the entire colony with the half-naked body. Consequently, she drowned herself in a well, and her parents claim that it's good that this slut died since she vilified them. It's always normalized to blame women and assess their disposition. And, Sakharam remarried within six months. The autobiographer exhibits both Dalit men and women's hypocrisy, prejudices, and narrow mindedness of people who cannot accept equal space and freedom for women and label women as characterless. Women's dignity has always been undervalued and put under a skeptic lens, and in the case of Dalit women, they are the most vulnerable section of the world. It is easier to brand them characterless because they are easily available at public workplaces. These abovementioned narratives reveal entrenched patriarchy of the Dalit community and find no difference between the existing state of women in savarna and avarna community. Even in the Dalit community, Dalit men's behavior towards their women seemed to be inspired by the feudal mindset.

The stigma of caste chased them everywhere irrespective of their good economic position, as the author's husband becoming a labor inspector posted in Bihar, and before he reaches there, the entire staff was aware of his Dalit identity and its polluting effect. The peon was a 'Bhumihar' from Bihar, and the clerk was a Kayasth. This Brahman peon didn't want to work under the command of a Dalit officer. On the contrary, he used to borrow all the edibles and utensils from the author and cooks for himself,

\footnotetext{
${ }^{16}$ Ibid., p. 72.

${ }^{17}$ Ibid., p. 73.
} 
maintaining distance from her child. Hence, the author scolded him in such words, "Do not you feel polluted while cooking food having our ration in our utensils? Then he shamelessly laughed." ${ }^{18}$ When he got posted in Asansol, here clerk was Brahman Jha, who also had the same attitude of being superior started creating troubles in his work by hiding letters. Devendra bears lots of difficulties and complaints about delayed work, that's what this clerk aimed. Afterward, his mischievous deeds get exposed, and Devendra suspended him. On his suspension, he started crying and started begging with folded hands and even touched their feet. She illustrates the double standards of Brahmins. As she argues, "Brahmin touches the feet [of anyone] for his self-interest. At that time, his superiority disappears." 19 Now the question is, "can a Dalit individual cease to be a Dalit after accumulating a certain amount of privilege and choosing to stop articulating their livid experience of victimhood."20 Because the abovementioned experience also implies that to equate Dalit privilege and homogenize it with upper-caste privilege is not justified at all that is visible from Baisantry's narrative, though it cannot be denied that 'urban-Dalits' or richer-Dalits' have relatively privileged circle than those of 'rural-Dalits or poor-Dalits.

Furthermore, the narrator's act of a letter-writing to those casteist 'chit-fund' women who blamed the author for hiding her caste identity shows her firm resistance and assertion, and she said, "you did not ask about my caste. Should I fix my caste identity poster on my back? You don't seem civilized. A civilized person does not believe in the caste system, and I do not keep friendships with people who are casteist. If I would have earlier known that you believe in caste, then I do not participate in your chit-fund. People of your caste have persecuted our fathers and grandfathers for centuries. Now you cannot dominate us. Why should I be afraid of you?"21 This Chit-fund narrative reflected the traditional nature of the Brahman family and their firm leaning to the caste system and exposed the real face of people at urban places.

The narrator boarded on a new journey of social work for Dalit women's cause, forming a Dalit women organization 'Mahila Samta Samaj.' And during her interaction with Dalit men and women for spreading

${ }^{18}$ Ibid., p. 103.

${ }^{19}$ Ibid., p. 103.

${ }^{20}$ Khobragade, Prateek. In Defence of "Caste Matters.” 26 August 2019.

${ }^{21}$ Baisantry, Kaushalya. p. 116. consciousness to raise their voice, she learned some astonishing facts about Dalit men's hypocritical attitude towards Dalit women's activism. They are fond of delivering fancy speeches at meetings for women's massive participation in social work and activism. When Dalit women activists asked them to let their wives come and participate in women's cause, they stopped their wives. Instead made derogatory remarks about women activists, as one of the Dalit women tells that, yet "My husband permitted in front of you that if I wish, I can go, but he started saying that these women do unnecessary work, they spoil houses."22 Subsequently, another organization 'Mahila Jagrati Parishad' was founded for scavengers and women's cause, but it couldn't succeed due to the indifference of Dalit and their acceptance of miserable conditions as their destiny.

Further, she draws light on mainstream women organizations or Indian feminism, and it's indifference and neglecting attitude regarding Dalit women issues which fail to underline Dalit women's questions. Mainstream Indian feminism saw all women as same, so are the problems faced by them, but the emergence of Dalit feminism in India challenged this idea of homogeneity among all women's issues. In short Dalit feminism argues that instead of looking caste and gender categories as the exclusive ones, rather, they should be seen as intersectional. Thorat argues, "the issue of the feminism of Dalit, Adivasi, and Minority women needs to be considered carefully. The life experiences of Dalit and Adivasi women are different; they are life and death issues rarely seen and articulated in the middle class urban feminist movement." 23 They need to come forward and fight independently from mainstream feminism that requires Dalit women's unified struggle to accomplish the objective. Repeated experience of the narrator finds that Dalits would have to fight separately from sarvarna women's organization; otherwise, a Dalit voice shall be lost. Going through the troubling experience of the Dalit community, the narrator argues that her people/community are/is devoid of the passion of change for their betterment. Also, men of her community themselves stop their women from working for society/community.

\footnotetext{
${ }^{22}$ Ibid., p. 121.

${ }^{23}$ Thorat, Vimal. Dalit Women's Voices Must Define Indian

Feminism. 21 May 2016.
} 


\section{CONCLUSION}

Thus, this narrative exhibits Dalit women's journey from subservient and non-assertive role to assertive and autonomous identity in the making towards constant upward mobility. The assertion of identity is the only hope for marginalized, oppressed, excluded, and otherised peoplefor the sake of their dignity, self-respect, and agency. But, Baisantry's journey of struggle and accomplishment is against all the odds and had to beat all the structural barriers to become part of Indian society. Also, through the act of writing the narrator emerged into a new identity with visionary and revolutionary itineraries to constitute a new world. Nonetheless, women's narratives are the portrayal of the most oppressed section of female voices for their plights and equal rights as well as the construction of female self through their socio-political assertion and resistance. Women have been put as sexual-object or aestheticized as a beautiful subject without free will and rationality, having no autonomous agency. Though, life narratives of Dalit women are an intervention to stop being recognized by their traditionally assigned identity of passivity, motherhood, and as mere sexual objects.

\section{REFERENCES}

[1] Baisantry, Kaushalya. (1999). Dohra Abhishaap. Delhi: Parmeshwari Prakashan,

[2] Khobragade, Prateek. In Defence of Caste Matters. 26 August 2019.

https://roundtableindia.co.in/index.php?option=com_content\& view=article \&id=9711:in-defence-of-caste$\underline{\text { matters \&catid=129:events-and-activism\&Itemid }=195}$

[3] Kumar, Udaya. (2013). "Consciouness, Agnecy and Humiliation: Reflections on Dalit Lifewriting and subalternity." The Politcal Philosophies of Antonio Gramsci and B R Ambedkar: Itineraries of Dalits and Subaltern. Edited by Cosimo Zene. New York: Routledge,

[4] Naik, Purnachandra. "Baby Kambale to Bama: Dalit Women Write Differently", Economic and Political Weekly Vol. No. 42, October 15, 2016.

[5] Thorat, Vimal. Dalit Women's Voices Must Define Indian Feminism. $21 \quad$ May 2016. https://sabrangindia.in/interview/dalit-womens-voices-mustdefine-indian-feminism-vimal-thorat

[6] Thorat, Vimal. Caste and Gender in Dalit Feminist Writing. http://twocircles.net/2015may24/1432488896.html 